\title{
Genetic homogeneity in the commercial pink shrimp Farfantepenaeus paulensis revealed by COI barcoding gene
}

\author{
S.S.A. Teodoro ${ }^{\text {a }}$, M. Terossi ${ }^{\mathrm{b}}$, R.C. Costa ${ }^{\mathrm{a}}$, F.L. Mantelatto ${ }^{\mathrm{b},{ }^{*}}$ \\ a Laboratory of Biology of Marine and Freshwater Shrimp (LABCAM), Department of Biological Sciences, Faculty of Sciences, University of State of São Paulo \\ (UNESP), Av. Eng. Luiz Edmundo Corrijo Coube, 14-01, CEP 17033-360, Bauru, SP, Brazil \\ ${ }^{\mathrm{b}}$ Laboratory of Bioecology and Crustacean Systematics (LBSC), Department of Biology, Faculty of Philosophy, Science and Letters at Ribeirão Preto (FFCLRP), \\ University of São Paulo (USP), CEP 14040-901, Ribeirão Preto, SP, Brazil
}

\section{A R T I C L E I N F O}

\section{Article history:}

Received 14 August 2014

Received in revised form

28 April 2015

Accepted 12 July 2015

Available online 15 July 2015

\section{Keywords:}

Cytochrome oxidase I

Fishery stocks

Gene flow

Genetic homogeneity

Penaeidae

\begin{abstract}
A B S T R A C T
The pink shrimp Farfantepenaeus paulensis is one of the most commercially exploited species in Brazil's South and Southeastern regions. Specific information about the status of its genetic variation is necessary to promote more effective management procedures. The genetic variation of the population of $F$. paulensis was investigated in five localities along southern and southeastern coast of Brazil. Sampling was performed with a commercial fishing boat. Total genomic DNA was extracted from abdominal muscle tissues and was used to DNA amplification by PCR. The COI gene was used as a DNA barcoding marker. The $570 \mathrm{bp}$ COI gene sequences were obtained from all 45 individuals. The haplotype network showed no genetic variability among the population stocks, which was confirmed by Molecular Variance Analysis. The final alignment showed that inside species there is haplotype sharing among the sampled localities, since one haplotype is shared by 38 individuals belonging to all the five sampled regions, with no biogeographic pattern. This result is reasonable since there are no geographical barriers or habitat disjunction that might serve as a barrier to gene flow among the sampled localities. Possible reasons and consequences of the genetic homogeneity found are discussed. The results complement ecological studies concerning the offseason: since it is a single stock, the same protection strategy can be applied. However, the genetic homogeneity found in this study combined with the intensive fishery effort and the species biology can result in severe consequences for the $F$. paulensis.
\end{abstract}

() 2015 Elsevier Ltd. All rights reserved.

\section{Introduction}

The pink shrimp Farfantepenaeus paulensis (Pérez-Farfante, 1967 ) is one of the most exploited species in Brazil (Paiva, 1997). It is distributed from Bahia - Brazil to Buenos Aires - Argentina, and found at 40-80 m deep (D'Incao, 1995; Costa et al., 2003). Individuals of this species, as well as individuals of the congener Farfantepenaeus brasiliensis (Latreille, 1917), are together known as "pink shrimps", and usually do not occur distinction between them at assessments of fishery stocks (Brisson, 1981; Chagas-Soares et al., 1995).

F. paulensis is more often captured between Ubatuba and Santos (São Paulo State), where cold waters are very close to the shore, and

\footnotetext{
* Corresponding author.

E-mail addresses: sarahteodoro@gmail.com (S.S.A. Teodoro),mterossi@usp.br (M. Terossi), rccosta@fc.unesp.br (R.C. Costa), flmantel@usp.br (F.L. Mantelatto).
}

southward is the dominant species of pink shrimp, being the only one present in Patos Lagoon (Rio Grande do Sul State) (Paiva, 1997). The size of the individuals and the mature female ratio increases with depth, and spawning occurs in colder waters, beyond the $50 \mathrm{~m}$ isobaths; juveniles are usually found in estuaries or bays (Costa et al., 2008). Distribution in this species is more related to depth than to latitudes (Zenger and Agnes, 1977).

Pink shrimps represented $18 \%$ of Brazilian total production (57,344.8 t) of marine crustaceans in 2011 (IBAMA, 2011). The general shrimp production is related to pink shrimp capture, which varies in function of the artisanal fishery in Patos Lagoon, South Brazil (D'Incao et al., 2002). The state of Rio Grande do Sul (extreme south of Brazil) is the major producer, with catches exclusively performed by artisanal system, acting on the juvenile population in a very intensively way (D'Incao et al., 2002). São Paulo and Rio de Janeiro states (Southeastern Brazil) are respectively the third and fourth producers, with catches mostly performed by industrial systems and on adult stocks (Paiva, 1997). 
Genetic variations among stocks may provide direct information on the populations of a species over a geographic area of distribution (Dumont, 2008). Evaluations of population genetic structure and intraspecific genetic diversity supply data of biological and evolutionary interest and are of great value for the successful conservation or management of exploited species (McMillen-Jackson and Bert, 2004). Molecular techniques have been applied with success to support fishery issues, such as the identification of genetic variation, population structure and reproductive isolation among groups (Benzie, 2000). These techniques seems to be more reliable tools for conservation studies, helping on the identification of reproductive isolation among stocks and thus allowing the delineation fishery management units and to assess which are conservation priorities, from an evolutionary perspective (Begg et al., 1999).

Nowadays, the legal annual offseason for shrimps in southern Brazil extends from March to May (Paiva, 1997; Costa et al., 2008). The offseason was established basing on the juvenile recruitment of the pink shrimp species F. brasiliensis and F. paulensis, and ecologic studies have shown that present offseason coincides with the major recruitment of such species (Branco and Verani, 1998; Costa and Fransozo 1999). However, there are still few studies concerning the genetic variation of F. paulensis in South and Southeastern Brazil, making it difficult to assess if the offseason period can be applied to the entire population of the species. As example, we can cite the study of Gusmão et al. (2005) using allozymes, in which they found populations of $F$. paulensis that are genetically structured, comprising two different fishery stocks (one for South and another for Southeast Brazil).

A better understanding of the structure of these populations, including the role of fisheries in the context of human and environmental impacts, is necessary for the development of conservation policies and restoration in the marine system (Blaber et al., 2000). In this context, the pink shrimp F. paulensis represents one of the most exploited fishery stocks in Brazil's South and Southeastern regions. Specific information about the status of its genetic variation is necessary to promote more effective management procedures. Considering the great economic importance of pink shrimp fishery in Brazil and the consequent and visible decrease in its populations, we aimed to analyze the genetic variation of F. paulensis in five localities along southern and southeastern coast of Brazil.

\section{Material and methods}

\subsection{Sampling}

Sampling of fresh specimens was performed at three localities along São Paulo state, Brazil: north region (Ubatuba, $23^{\circ} 26^{\prime}$ S, $45^{\circ} 04^{\prime} \mathrm{W}$ ), central region (Santos, $23^{\circ} 57^{\prime} \mathrm{S}, 46^{\circ} 19^{\prime} \mathrm{W}$ ) and south region (Cananéia, $25^{\circ} 1^{\prime} \mathrm{S}, 47^{\circ} 55^{\prime} \mathrm{W}$ ) (Fig. 1). Geographic coordinates related to the sampled points were recorded using a GPS (Global positioning system).

Sampling was performed on February and August 2012, with a commercial fishing boat equipped with otter-trawl and double-rig nets (mesh size $18 \mathrm{~mm}$ and $20 \mathrm{~mm}$, respectively) and mouth opening of $5 \mathrm{~m}$, which was hauled for $30 \mathrm{~min}$. The biological material was stored in ice, identified according to specific keys (Costa et al., 2003), preserved in 75-90\% ethyl alcohol and deposited in the Crustacean Collection of the Department of Biology, Faculty of Philosophy, Science and Letters at Ribeirão Preto, University of São Paulo (CCDB/FFCLRP/USP), Brazil. Complementary specimens from other two localities (Rio Grande do Sul and Rio de Janeiro states) and previously cataloged in the CCDB collection were analyzed (Fig. 1).

\subsection{Molecular analysis}

Total genomic DNA was obtained from the abdominal muscle tissues of individuals. This procedure has the advantage of being performed from small amounts of biological tissue. Obtaining and manipulation of genetic material are in accordance with SISBIO license for sampling and genetic analysis of decapods, (CGEN No. 11777-1, Issue Date: 09/16/2007 to FLM). The COI gene has been frequently used with success to analyze phylogenetic relationships in many marine crustaceans, including species of Penaeus and other Decapoda (Quan et al., 2001). This gene was chosen for molecular analysis due to its wide variability in evolutionary rates (Moritz et al., 1987), allowing to verify the occurrence of inter-population variation within species, as already done in other studies with shrimps (Gusmão et al., 2000; Vergamini et al., 2011; Terossi and Mantelatto, 2012; Rossi and Mantelatto, 2013). The COI gene is also used as a "barcode" marker for most living animal (Hebert et al., 2003).

The protocol for extraction of specimens was based on the work of Mantelatto et al. (2007, 2009). Muscle tissues extracted from each individual were placed in lysis buffer and proteinase $\mathrm{K}$ $(500 \mu \mathrm{g} / \mathrm{mL})$ and then incubated for $24 \mathrm{~h}$ at $55^{\circ} \mathrm{C}$. After dry bath prior to centrifugation, $200 \mu \mathrm{L} \mathrm{NH}_{4} \mathrm{OAc}(7.5 \mathrm{M})$ was added in each sample; after this, $600 \mu \mathrm{L}$ of cooled isopropanol was added, so decanting the DNA. After $48 \mathrm{~h}$ of samples cooled at $20^{\circ} \mathrm{C}$, the resulting pellet was washed with $15 \mu \mathrm{L}$ of $70 \% \mathrm{EtOH}$, centrifuged, freeze-dried in an Eppendorf Concentrator $5301^{\circledR}$ and resuspended in $20 \mu \mathrm{L}$ of TE buffer. The concentration of the extracted DNA from each sample was measured in a Nanodrop spectrophotometer $2000^{\circledR}$.

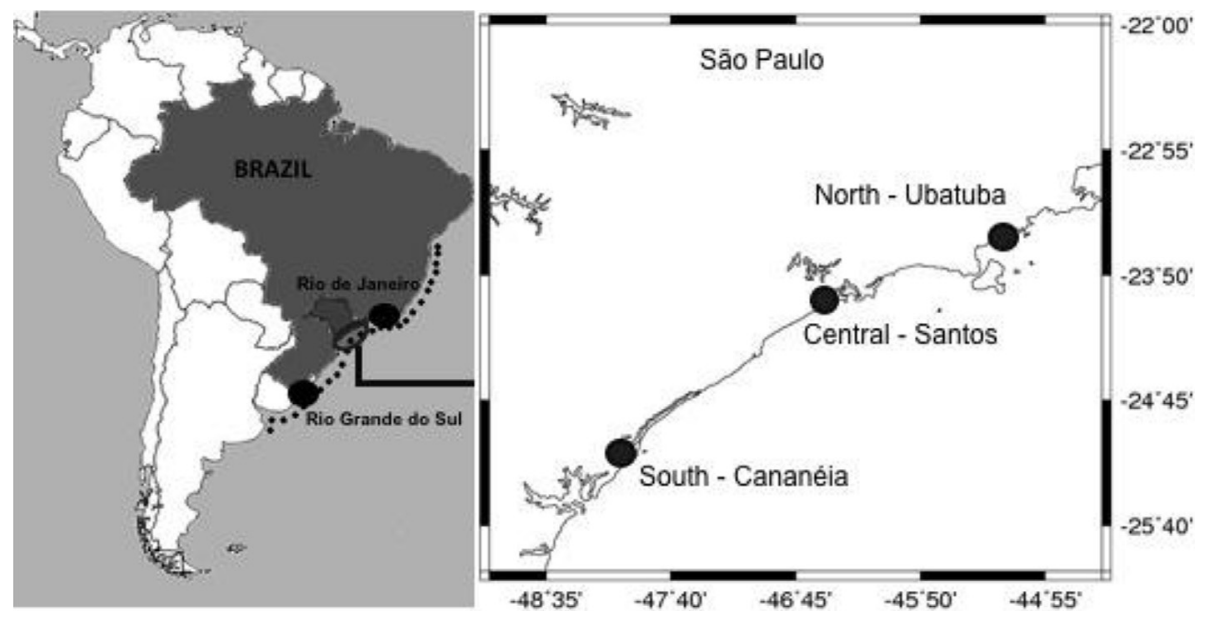

Fig. 1. Map showing the five sampled regions of the present study. Small dots indicate the known distribution of $F$. paulensis. 
Table 1

Specimens of Farfantepenaeus paulensis used in genetic analyses. N: number of individuals; CCDB/FFCLRP/USP: Crustacean Collection of the Department of Biology, Faculty of Philosophy, Sciences and Letters at Ribeirão Preto, University of São Paulo.

\begin{tabular}{lcll}
\hline Localities & $\mathrm{N}$ & CCDB/FFCLRP/USP & Genbank Access \\
\hline Rio de Janeiro & 2 & CCDB 4285 & KM065406 \\
& & CCDB 4285 & KM065413 \\
São Paulo (Ubatuba) & 8 & CCDB 4484 & KF989424 - KF989431 \\
São Paulo (Santos) & 9 & CCDB 4482 & KF989448 \\
& & CCDB 4482 & KF989450 - KF989457 \\
São Paulo (Cananéia) & 16 & CCDB 4483 & KF989437- KF989448 \\
Rio Grande do Sul & 10 & CCDB 4946 & KM065407 - KM065412 \\
& & CCDB 4679 & KF989458 - KF989461 \\
\hline
\end{tabular}

Samples with DNA concentrations were used for amplification by PCR (polymerase chain reaction) in a thermocycler Veriti Applied Biosystems ${ }^{\circledR}$. Amplification was performed using the primers HCO1-2198 (TAA ACT TCA CCA AAA TGA AAT GGG CA) and LCO1-1490 (GGT CAA CAA ATC ATA ATA AAG TTG) (Folmer et al., 1994). The choice of primers was based on the applicability of the data, which may be used for future phylogenetic studies and DNA barcoding system. PCR products were obtained in a total reaction volume of $25 \mu \mathrm{L}$, containing ultrapure $\mathrm{H}_{2} \mathrm{O}, \mathrm{PCR}$ buffer $(10 \times), \mathrm{MgCl}_{2}$ (25 mM), betaine ( $5 \mathrm{mM}), 1 \%$ BSA solution, dNTPs $(10 \mathrm{mM})$, primers $(20 \mu \mathrm{M})$, Thermus aquaticus polymerase $(5 \mathrm{U} / \mu \mathrm{L})$ and $140 \mathrm{ng}$ of the previously extracted DNA. The DNA amplification by PCR method was carried out using thermal cycle with an initial denaturation for $2 \mathrm{~min}$ at $94{ }^{\circ} \mathrm{C}$, annealing for 35 cycles $\left(30 \mathrm{~s}\right.$ at $94{ }^{\circ} \mathrm{C}, 30 \mathrm{~s}$ at $46-50{ }^{\circ} \mathrm{C}, 1 \mathrm{~min} 72^{\circ} \mathrm{C}$ ) and final extension of $2 \mathrm{~min}$ at $72^{\circ} \mathrm{C}$. Results of each PCR were observed in electrophoresis with $1.4 \%$ agarose gel and photographed with a digital camera Olympus C-7070 ${ }^{\circledR}$ on a UV transilluminator UVP ${ }^{\circledR}$ Transilluminator M20.

Amplified DNA was purified with the purification kit SureClean $^{\circledR}$, according to the company protocol. After purification, samples with concentration higher than $10 \mathrm{ng} / \mu \mathrm{l}$ in a volume of $20 \mu$ l were sent to the Department of Technology, Faculty of Agricultural Sciences and Veterinary Jaboticabal, Universidade Estadual Paulista, where reactions of preparation for sequencing and subsequent sequencing were performed, using the HCO1-2198 primer.

\subsection{Data analysis}

Sequence editing was performed in the program BioEdit version 7.0.9 (Hall, 1999). The DNA fragments were aligned on BLAST system for comparison with the assembly of NCBI database (http:// blast.ncbi.ncbi.nlm.nih.gov/blast.cgi) in order to confirm their respective identities. Testimony specimens of these sequences were listed (CCDB/FFCLRP/USP, Table 1) and are therefore the genetic voucher. All new sequences obtained in this study were deposited in GenBank (Table 1). Haplotype analyzes followed the methods used by Vergamini et al. (2011) aiming comparison among locations and among species. Sequences were previously aligned with pre-defined parameters in Clustal W program (Thompson et al., 1994), implemented in the program BioEdit 7.0.9. Then, a construction of a genetic divergence matrix was performed, based on the Kimura2-parameters model (Kimura, 1980) in the MEGA program version 5 (Tamura et al., 2011).

The number of haplotypes was calculated in the program DnaSP 4.10.9 (Rozas and Rozas, 1999), and haplotype networks were constructed by median-joining method in the Network program (Bandelt et al., 1999), with data preparation in DnaSP program. Genetic difference of the groups here studied was analyzed by Analysis of Molecular Variance (AMOVA) (Excoffier et al., 1992), considering the variation at each nucleotide site separately, in the program Arlequin 3.1 (Excoffier et al., 2005). This analysis allows us to estimate the level of intraspecific genetic subdivision, considering the variation of gene frequencies, (1) among localities (Rio de Janeiro, Ubatuba, Santos, Cananéia and Rio Grande do Sul), and (2) within localities (i.e., among individuals).

\section{Results}

In total, 45 individuals of $F$. paulensis were analyzed, from which the 570 bp COI gene sequences were obtained. The intra-specific genetic distance did not separate populations among localities (Table 2), ranging from 0 to $0.6 \%$.

Based on partial fragments of the COI gene of the 45 specimens from the five sampled localities (Rio de Janeiro, Ubatuba, Santos, Cananéia and Rio Grande do Sul), 8 haplotypes were defined $(\mathrm{H})$, from which 7 (approximately 90\%) represented individual haplotypes, i.e., they were found in one individual only. The haplotype network showed that one haplotype is shared by 38 individuals belonging to all the five sampled regions. This analysis did not reveal any genetic structure among groups that can be understood as genetic homogeneity (Fig. 2).

Haplotype diversity (Hd) was calculated as 0.3431 . Most of the genetic diversity was the result of variation within rather than among regions (AMOVA: within regions $=103.03 \%$, among regions $=-3.03 \%$, Fst $=-0.030, \mathrm{P}=0.71$ ). This high P-value indicates non-statistically significant differences in the frequencies of the COI sequences examined between the analyzed populations. The average nucleotide composition for F. paulensis was $19.20 \%$ (C), $35.90 \%(\mathrm{~T}), 26.07 \%(\mathrm{~A})$ and $18.84 \%(\mathrm{G})$.

\section{Discussion}

There was no genetic separation among the five sampled localities, as evidenced by analysis of genetic divergence, haplotype network and AMOVA. This result is reasonable since there are no geographical barriers among the localities and may be related with the shrimp general life history of the genus Farfantepenaeus. The life cycle of $F$. paulensis includes spawning in oceanic waters and a period of initial life development in the estuary, as described by Type II life cycle proposed by Dall et al. (1990). The genetic homogeneity over $F$. paulensis distribution can be associated to the high capacity of planktonic larval dispersal, hampering the population establishment over its geographical range (Gopurenko and Hughes, 2002). Genetic analyses of marine population showing a

Table 2

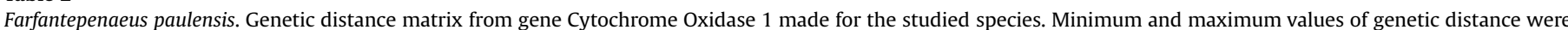
grouped (Kimura-2-Parameters).

\begin{tabular}{|c|c|c|c|c|c|}
\hline & 1 & 2 & 3 & 4 & 5 \\
\hline 1. Rio de Janeiro & 0.000 & & & & \\
\hline 2. Ubatuba & 0.000 & 0.000 & & & \\
\hline 3. Santos & $0.000-0.002$ & $0.000-0.002$ & $0.000-0.002$ & & \\
\hline 4. Cananéia & $0.000-0.004$ & $0.000-0.006$ & $0.000-0.006$ & $0.000-0.006$ & \\
\hline 5. Rio Grande do Sul & $0.000-0.004$ & $0.000-0.004$ & $0.000-0.006$ & $0.000-0.006$ & $0.000-0.006$ \\
\hline
\end{tabular}




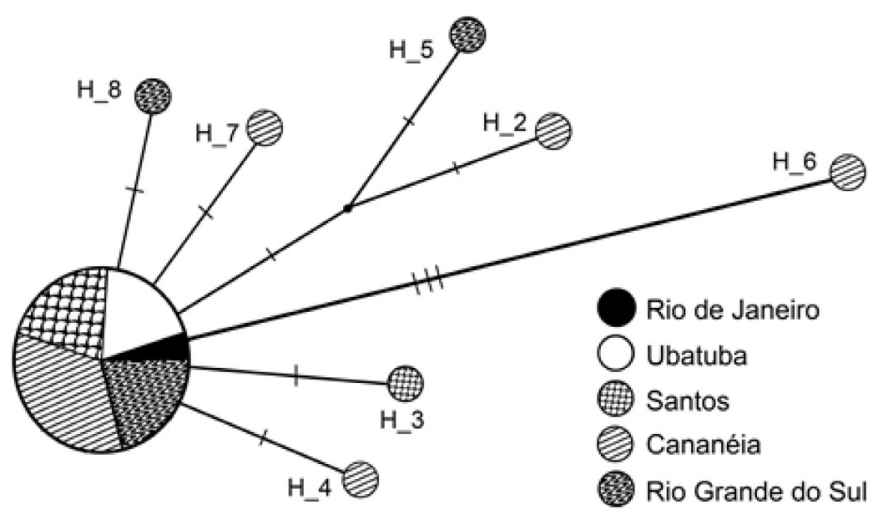

Fig. 2. Haplotype network according to Median-Joining analysis. Each circle represents one haplotype found in the localities ( 8 haplotypes in 45 specimens). The number beside circle corresponds to the haplotype number. The size of the circle of each haplotype is proportional to its frequency in the sample. Each small trace represents a mutational step.

slight or low geographical variation are common in species with high dispersal potential (Palumbi, 2003). In addition, the dynamics of water masses could facilitate the gene flow among the localities sampled in this study.

Three water masses strongly influence the study area: the South Atlantic Central Waters, with low temperature and salinity; Tropical Waters, with salinity and high temperatures; and Coastal Waters, with high temperature and low salinity (Castro-Filho et al., 1987). These water masses interact and modify the temperature, salinity and nutrient conditions during the seasons (Castro et al., 2005). Salinity and temperature influence spatial distribution of $F$. paulensis (Tsuzuki et al., 2003; Costa et al., 2008), so water masses may also be actuating in the displacement of this species, directing its distribution and consequently the gene flow.

The penaeid Artemesia longinaris Spence Bate, 1888 also showed a genetic homogeneity among the population along its geographical distribution (Carvalho-Batista et al., 2014). Artemesia longinaris and $F$. paulensis have very similar distributions, and the FST value found $(-0.02)$ was similar to that obtained in this present study $(-0.03)$, reflecting the absence of geographical genetic structure. Negative FST values are usually associated with the imprecision of algorithms used in this kind of analysis, and can be interpreted as zero in these cases of species with high genetic variation and few shared haplotypes (Winkelmann et al., 2013).

In South America, other studies using COI gene with different groups of decapods have found no structuration among different localities: Laurenzano et al. (2012), with fiddler crab Uca uruguayensis (Nobili, 1901); Rossi and Mantelatto (2013), with estuarine shrimp Macrobrachium olfersii (Wiegmann, 1836); Wieman et al. (2013), with Uca maracoani (Latreille, 1802-1803); and Laurenzano et al. (2013), with Uca rapax, Smith 1870. However, when analyzing the population structure of $F$. paulensis using allozymes, Gusmão et al. (2005) found that the studied populations were genetically structured in two different stocks (one from South and other from Southeast Brazil). Besides the use of different markers, these authors may have found a temporal variation of allozymes. Usually genetic studies assume that the observed patterns remain stable over time and that changing factors have little or no effect in short periods of time (Barcia et al., 2005), but intrinsic factors associated to the life cycle of each species could mold their genetic patterns (McMillen-Jackson and Bert, 2003). Some events - such as sudden weather changes, droughts and other natural or anthropogenic disturbing factors - are completely independent of the species' biological properties (Allison et al.
2003), so multiple factors can affect the temporal stability of allele frequencies in natural populations and genetic structure of a species could significantly change in time (Barcia et al., 2005). With the fact of different genetic markers been used, this could explain the divergences found between the present study and Gusmão et al. (2005). The inclusion in the analysis of specimens from more distant locations and from different time periods, covering the complete range of distribution through generations, and using more specific markers (as microsatellites, for instance) could be important to better understand the genetic variation of the species.

McMillen-Jackson and Bert (2003) compared the phylogenetic structure and biogeography of the brown shrimp Farfantepenaeus aztecus (Ives, 1891) and the white shrimp Litopenaeus setiferus (Linnaeus, 1767) in the eastern United States. For F. aztecus there was no significant phylogenetic structure and the near-shared haplotypes were geographically dispersed, while for $L$. setiferus the haplotypes were geographically structured. In the same area of study, McMillen-Jackson and Bert (2004) found no difference in the population of Farfantepenaeus duorarum (Burkenroad, 1939), suggesting a long-term distribution and gene flow high enough to maintain a genetically homogeneous population structure, along the studied geographic distance. This may be the same situation of F. paulensis, since it has no habitat disjunction that might serve as a barrier to gene flow among the sampled localities. The continuous range of appropriate pink shrimp habitat around the South and Southeastern Brazilian coast could offer a pathway for shortdistance dispersal of the benthic juveniles and adults, as with $F$. duorarum (McMillen-Jackson and Bert, 2004).

Based on our set of analysis, the origin of the stock of $F$. paulensis are probably the breeding grounds off Santa Catarina State (Southern Brazil), as already supposed by previous studies (D'Incao, 1991; Deledove, 1996; Gusmão et al., 2005). The area is under extensive exploitation and represents $20 \%$ of total Brazil's fishing trawlers (Leite and Petrere, 2006). However, harvesting a group of individuals that originates several subpopulations can result in the extirpation of one or more subpopulations (Allendorf et al., 2008). Actually, pink shrimp populations have declined $87 \%$ in less than 40 years (Neto and Dornelles, 1996). Reduced population size due to fishery can also reduce the number of migrants and cause the loss of genetic variation within subpopulations, reducing their productivity both by reducing individual fitness in the short term and by reducing the ability of subpopulations to evolve in the future (Ryman et al., 1995).

The homogeneity found in the present study could also be the consequence of a bottleneck effect. The theoretical relationship between population bottlenecks and the loss of genetic variation is well established (Wright, 1931; Nei et al., 1975; Chakraborty and Nei, 1977). Demographic bottlenecks occur when populations experience severe and temporary reductions in size and may influence the distribution of genetic variation within and among populations (Spencer et al., 2000). The pink shrimp fishery in South Brazil collapsed in the 90's, where the lowest total stock catch (2008 tons) occurred in 1998 (D'Incao et al., 2002). Considering that Santa Catarina is probably the seeding population, a high rate of exploitation (as the fishery collapse reported), especially of juveniles, could exacerbate the magnitude of natural population fluctuations and thereby reduce the effective population size over time (Koljonen, 2001). The smaller size of a population and the longer it remains small, the genetic variation it will lose (Leberg, 1992). Additionally, fishery usually targets specific sex or age classes and thereby can reduce the effective population size and increase the rate of loss of genetic variation (Allendorf et al., 2008). For instance, the size at sexual maturity in the rock lobster Panulirus cygnus off the west coast of Australia has declined substantially over the past 35 years (Melville-Smith and Lestang, 2006). This change seems to 
be partially an evolutionary response to extremely high exploitation rates of adults combined with a required minimum carapace length in harvested animals. The understanding of the genetic changes and evolutionary responses of exploited populations is crucial for the design of management aimed at sustainable exploitation of natural biological resources (Walsh et al., 2006; Allendorf et al., 2008).

Genetic homogenization of populations can also influence the capacity of a species to expand its distribution (Olden et al., 2004). F. paulensis shows a restricted geographical distribution and higher occurrence in cold waters, features that differ from other western Atlantic penaeids as F. brasiliensis and Farfantepenaeus subtilis, species with larger distributions and warmer water occurrence (D'Incao, 1995; Costa et al., 2003). Geographic range size is a strong predictor of extinction risk (Gaston and Fuller, 2009). The genetic homogenization combined to a restricted distribution and limitation to cold waters could lead $F$. paulensis to become more sensitive to changes as consequences for anthropic actions, such as exploitation, global warming and ocean acidification. Increases in the temperature of tropical and subtropical waters over the past 50 years have already pushed marine organisms close to their thermal limits (Hoegh-Guldberg, 1999; Hoegh-Guldberg et al., 2007). Furthermore, pink shrimp fishery collapsed in the past and nowadays is at its maximum sustainable yield (Leite and Petrere, 2006), a fact that aggravates $F$. paulensis situation. Genetic changes caused by exploitation can increase extinction risks and reduce recovery rates of over-harvested populations (Olsen et al., 2004; Walsh et al., 2006).

When managing a species as a resource, assessment of population genetic variation and structure can be a vital tool for maintaining a productive fishery (Seeb et al., 1990). Although the large population sizes and high fecundities of exploited marine invertebrates tend to make these species less susceptible to population collapse, a combination of several factors - over-fishing, disease, habitat loss, and competition - can all contribute toward population decline (Hobday et al., 2001). Understanding the genetic changes and evolutionary responses of exploited populations is crucial for the design of management aimed at sustainable exploitation of natural biological resources (Walsh et al., 2006). Intense and prolonged mortality caused by exploitation will inevitably result in genetic change, but management plans should be developed by applying basic genetic principles combined with molecular genetic monitoring to minimize harmful genetic change (Allendorf et al., 2008).

\section{Conclusion}

Fishery along the $F$. paulensis distribution is the typical case in which the high exploitation, combined with an ineffective fisheries management, has resulted in a serious depletion of shrimp. South and southern Brazilian coast have been negatively impacted by overfishing, where the spawning stock may have been reduced to a level where the number of recruits produced can be insufficient to maintain the population. The present study found a genetic homogeneity for $F$. paulensis, comprising only one stock throughout its distribution. These results complement ecological studies concerning the offseason, since the closed period covers the pink shrimp juvenile recruitment and considering it is a single stock, the same protection strategy can be applied. However, the genetic homogeneity found in this study combined with the intensive fishery effort can result in severe consequences for the species, so studies focusing the conservation genetics of $F$. paulensis and based on long-term periods could help the planning of more effective management strategies.

\section{Acknowledgments}

This paper is part of the multidisciplinary research project Temático BIOTA-FAPESP (São Paulo Research Foundation), which aims to produce a fine-scale assessment of the marine decapod biodiversity of the State of São Paulo. Financial support for this project was provided by research grants from FAPESP (Temático Biota 2010/50188-8; grant 2011/16268-7). Additional support came from CAPES (Ciências do Mar II Proc. 2005/2014-23038.004308/ 2014-14). RCC (305919/2014-8) and FLM (304968/2014-5) received research scholarships from CNPq, and MT is grateful to FAPESP (PD 2011/11901-3). We also thank the LABCAM members for their help during fieldwork and to the anonymous reviewers for their great suggestions and contributions towards improving this article. All experiments conducted in this study comply with current applicable state and federal laws (Authorization of the Instituto Chico Mendes de Biodiversidade/ICMBio number 11274).

\section{References}

Allendorf, F.W., England, P.R., Luikart, G., Ritchie, P.A., Ryman, N., 2008. Genetic effects of harvest on wild animal populations. Tr. Ecol. Evol. 23 (6), 327-337. http://dx.doi.org/10.1016/j.tree.2008.02.008.

Allison, G.W., Gaines, S.D., Lubchenco, J., Possingham, H.P., 2003. Ensuring persistence of marine reserves: catastrophes require adopting an insurance factor. Ecol. Appl. 13 (1), S8-S24. http://www.jstor.org/stable/3099994.

Bandelt, H.J., Forster, P., Röhl, A., 1999. Median-joining networks for inferring intraspecific phylogenies. Mol. Biol. Evol. 16, 37-48. http://dx.doi.org/10.1093/ oxfordjournals.molbev.a026036. http://mbe.oxfordjournals.org/content/16/1/ 37.

Barcia, A.R., López, G.E., Hernández, D., García-Machado, E., 2005. Temporal variation of the population structure and genetic diversity of Farfantepenaeus notialis assessed by allozyme loci. Mol. Ecol. 14, 2933-2942. http://dx.doi.org/10.1111/ j.1365-294X.2005.02613.x.

Begg, G.A., Friedland, K.D., Pearce, J.B., 1999. Stock identification and its role in stock assessment and fisheries management: an overview. Fish. Res. 43, 1-8. http:// dx.doi.org/10.1016/S0165-7836(99)00062-4.

Benzie, J.A.H., 2000. Population genetic structure in penaeid prawns. Aquac. Res. 31, 95-119. http://dx.doi.org/10.1016/S0165-7836(99)00062-4.

Blaber, S.J.M., Cyrus, D.P., Albaret, J.-J., Ching, C.V., Day, J.W., Elliott, M., Fonseca, M.S., Hoss, D.E., Orensanz, J., Potter, I.C., Silvert, W., 2000. Effects of fishing on the structure and functioning of estuarine and nearshore ecosystems. ICES J. Mar. Sci. 57, 590-602. http://dx.doi.org/10.1006/jmsc.2000.0723.

Branco, J.O., Verani, J.R., 1998. Estudo populacional do camarão-rosa Penaeus paulensis Pérez-Farfante (Natantia, Penaeidae) na Lagoa da Conceição, Santa Catarina, Brasil. Rev. Bras. Zool. 15 (2), 353-364.

Brisson, S., 1981. A influência da temperatura e da periodicidade lunar' sobre a atividade biológica de Penaeus brasiliensis (Latreille), 137. Publicação do Instituto de Pesca e Mar, pp. 1-22.

Carvalho-Batista, A., Negri, M., Pileggi, L.G., Castilho, A.L., Costa, R.C., Mantelatto, F.L., 2014. Inferring population connectivity across the range of distribution of the stiletto shrimp Artemesia longinaris Spence Bate, 1888 (Decapoda: Penaeidae) from DNA barcoding: implications for fishery management. Zookeys 457, 271-288. http://dx.doi.org/10.3897/zookeys.457.6569.

Castro, R.H., Costa, R.C., Fransozo, A., Mantelatto, F.L., 2005. Population structure of the seabob shrimp Xiphopenaeus kroyeri (Heller, 1962) (Crustacea: Penaeoidea) in the littoral of São Paulo, Brazil. Sci. Mar. 69 (1), 105-112. http://dx.doi.org/ 10.3989/scimar.2005.69n1105.

Castro-Filho, B.M., Miranda, L.B., Myao, S.Y., 1987. Condições hidrográficas na plataforma continental ao largo de Ubatuba: variações sazonais e em média escala. Bol. do Inst. Oceanogr. 35 (2), 135-151. http://dx.doi.org/10.1590/S037355241987000200004.

Chakraborty, R., Nei, M., 1977. Bottleneck effects on average heterozygosity and genetic distance with the stepwise mutation model. Evolution 31 (2), 347-356.

Chagas-Soares, F., Pereira, O.M., Santos, E.P., 1995. Contribuição ao ciclo biológico de Penaeus schmitti Burkenroad, 1936, Penaeus brasiliensis Latreille, 1817 e Penaeus paulensis Pérez-Farfante, 1967, na região Lagunar-Estuarina de Cananéia, São Paulo, Brasil. Bol. do Inst. Pesca 22 (1), 49-59.

Costa, R.C., Fransozo, A., Melo, G.A.S., Freire, F.A.M., 2003. An illustrated key for Dendrobranchiata shrimps from the northern coast of São Paulo, Brazil. Biota Neotrop. 3, 1-12. http://www.biotaneotropica.org.br/v3nl (accessed in 05.05.14.).

Costa, R.C., Lopes, M., Castilho, A.L., Fransozo, A., Simões, S.M., 2008. Abundance and distribution of juvenile pink shrimps Farfantepenaeus spp. in a mangrove estuary and adjacent bay on the northern shore of São Paulo State, southeastern Brazil. Invertebr. Reprod. Dev. 52 (1-2), 51-58. http://dx.doi.org/10.1080/ 07924259.2008 .9652272$.

Costa, R.C., Fransozo, A., 1999. A nursery ground for two tropical pink-shrimp Farfantepenaeus species: Ubatuba Bay, northern coast of São Paulo, Brazil. Nauplius 7, 73-81. 
D'Incao, F., 1991. Pesca e biologia de Penaeus paulensis na Lagoa dos Patos, RS. Atlântica 13 (1), 159-169.

D'Incao, F., 1995. Taxonomia, Padrões distribucionais e ecológicos dos Dendrobranchiata (Crustacea: Decapoda) do litoral brasileiro (Ph.D. thesis). Universidade Federal do Paraná, Curitiba, PR, Brazil, p. 365. unpublished.

D'Incao, F., Valentini, H., Rodrigues, L.F., 2002. Avaliação da pesca de camarões nas regiões sudeste e sul do Brasil. Atlântica 24 (2), 103-116.

Dall, W., Hill, B.J., Rothlisberg, P.C., Staples, D.J., 1990. In: Blaxter, J.H.S., Southward, A.J. (Eds.), Advances Marine Biology, 2: the Biology of the Penaeidae, vol. 27. Academic Press, San Diego, pp. 1-489.

Delevedove, G.C.D., 1996. Genética populacional do camarão rosa Penaeus paulensis (Decapoda: Penaeidae) na região estuarina da Lagoa dos Patos, Rio Grande do Sul, e no litoral de Santa Catarina. Unpublished M.Sc. Thesis. Fundação Universidade do Rio Grande, Rio Grande, Brazil.

Dumont, L.F.C., 2008. Identificação de estoques e aspectos biológicos e pesqueiros do camarão-barba-ruça (Artemesia longinaris BATE, 1888 - Decapoda: Penaidae) (Ph.D thesis). Federal University of Rio Grande, RS, Brazil, p. 240 unpublished.

Excoffier, L., Smouse, P.E., Quattro, J.M., 1992. Analysis of molecular variance inferred from metric distances among DNA haplotypes: application to human mitochondrial DNA restriction data. Genetics 131, 479-491. http://www. genetics.org/content/131/2/479.full.pdf + html.

Excoffier, L., Laval, G., Schneider, S., 2005. Arlequin (version 3.0): an integrated software package for population genetics data analysis. Evol. Bioinforma. Online 1, 47-50. http://www.ncbi.nlm.nih.gov/pmc/articles/PMC2658868/.

Folmer, O., Black, M., Hoeh, W., Lutz, R., Vrijenhoek, R., 1994. DNA primers for amplification of mitochondrial cytochrome c oxidase subunit I from diverse metazoan invertebrates. Mol. Mar. Biol. Biotechnol. 3 (5), 294-299. http:// www.mbari.org/staff/vrijen/PDFS/Folmer_94MMBB.pdf.

Gaston, K.J., Fuller, R.A., 2009. The size of species' geographic ranges. J. Appl. Ecol. 46, 1-9. http://dx.doi.org/10.1111/j.1365-2664.2008.01596.x.

Gopurenko, D., Hughes, J.M., 2002. Regional patterns of genetic structure among Australian populations of the mud crab, Scylla serrata (Crustacea: Decapoda): evidence from mitochondrial DNA. Mar. Freshw. Res. 53, 849-857. http:// dx.doi.org/10.1071/MF01225.

Gusmão, J., Lazoski, C., Solé-Cava, A.M., 2000. A new species of Penaeus (Crustacea Penaeidae) revealed by allozyme and cytochrome oxidase I analyses. Mar. Biol 137, 435-446. http://dx.doi.org/10.1007/s002270000365.

Gusmão, J., Lazoski, C., Solé-Cava, A.M., 2005. Population genetic structure of Brazilian shrimp species (Farfantepenaeus sp., F. brasiliensis, F. paulensis and Litopenaeus schmitti: Decapoda: Penaeidae). Gen. Molec. Biol 28 (1), 165-171. http://dx.doi.org/10.1590/S1415-47572005000100029.

Hall, T.A., 1999. BioEdit: a user-friendly biological sequence alignment editor and analysis program for Windows 95/98/NT. Nucleic Acids Symp. Ser. 41, 95-98. http://www.mbio.ncsu.edu/JWB/papers/1999Hall1.pdf.

Hebert, P.D.N., Ratnasingham, S., De Waard, J.R., 2003. Barcoding animal life: cytochrome oxidase subunit 1 divergences among closely related species. Proc. $\mathrm{R}$ Soc. Lond. Ser. B Biol. Sci. 270 (1), S96-S99. http://dx.doi.org/10.1098 rsbl.2003.0025.

Hobday, A.J., Tegner, M.J., Haaker, P.L., 2001. Over-exploitation of a broadcast spawning marine invertebrate: decline of the white abalone. Rev. Fish Biol. Fish. 10, 493-514. http://dx.doi.org/10.1023/A:1012274101311.

Hoegh-Guldberg, O., 1999. Climate change, coral bleaching and the future of the world's coral reefs. Mar. Freshw. Res. 50 (8), 839-866. http://dx.doi.org/ 10.1071/MF99078.

Hoegh-Guldberg, O., Mumby, P.J., Hooten, A.J., Steneck, R.S., Freenfield, P., Gomez, E. Harvell, C.D., Sale, P.F., Edwards, A.J., Caldeira, K., Knowlton, N., Eakin, C.M Iglesias-Prieto, R., Muthiga, N., Bradbury, R.H., Dubi, A., Hatziolos, M.E., 2007. Coral reefs under rapid climate change and ocean acidification. Science 318 , 1737-1742. http://dx.doi.org/10.1126/science.1152509.

IBAMA, 2011. Boletim Estatístico da Aquicultura e Pesca no Brasil - ano 2011. Instituto Brasileiro do Meio Ambiente e dos Recursos Naturais Renováveis, Brasil, p. 60. Available. http://www.mpa.gov.br/index.php/informacoes-eestatisticas/estatistica-da-pesca-e-aquicultura, 13/01/2014

Kimura, M., 1980. A simple method for estimating evolutionary rates of base substitutions through comparative studies of nucleotide sequences. J. Mol. Evol. 16 (2), 111-120. http://dx.doi.org/10.1007/BF01731581.

Koljonen, M.L., 2001. Conservation goals and fisheries management units for Atlantic salmon in the Baltic Sea Area. J. Fish Biol. 59, 269-288.

Laurenzano, C., Farias, N.E., Schubart, C.D., 2012. Mitochondrial genetic structure of two populations of Uca uruguayensis fails to reveal an impact of the Rio de la Plata on gene flow. Nauplius 20 (1), 15-25. http://dx.doi.org/10.1590/S010464972012000100003.

Laurenzano, C., Mantelatto, F.L., Schubart, C.D., 2013. South American homogeneity versus Caribbean heterogeneity: population genetic structure of the wester Atlantic fiddler crab Uca rapax (Brachyura, Ocypodidae). J. Exp. Mar. Biol. Ecol. 449, 22-27. http://dx.doi.org/10.1016/j.jembe.2013.08.007.

Leberg, P.L., 1992. Effects of population bottlenecks on genetic diversity as measured by allozyme electrophoresis. Evolution 46 (2), 477-494. http://www.jstor.org/ stable/2409866.

Leite Jr., N.O., Petrere Jr., M., 2006. Stock assessment and fishery management of the Pink shrimp Farfantepenaeus brasiliensis Latreille, 1970 and F. paulensis PérezFarfante, 1967 in southeastern Brazil $\left(23^{\circ}-28^{\circ} \mathrm{S}\right)$. Braz. J. Biol. 66 (1b), 263-277. http://dx.doi.org/10.1590/S1519-69842006000200009.

Mantelatto, F.L., Robles, R., Felder, D.L., 2007. Molecular phylogeny of the Western
Atlantic species of the genus Portunus (Crustacea, Brachyura, Portunidae). Zool. J. Linn. Soc. 150 (1), 211-220. http://dx.doi.org/10.1111/j.10963642.2007.00298.x.

Mantelatto, F.L., Robles, R., Schubart, C.D., Felder, D.L., 2009. Chapter 29. Molecular phylogeny of the genus Cronius Stimpson, 1860, with reassignment of C. tumidulus and several American species of Portunus to the genus Achelous De Haan, 1833 (Brachyura: Portunidae). In: Martin, J.W., Crandall, K.A., Felder, D.L. (Eds.), Crustacean Issues: Decapod Crustacean Phylogenetics. Taylor \& Francis/ CRC Press, Boca Raton, Florida, pp. 537-551. http://dx.doi.org/10.1201/ 9781420092592-c29.

McMillen-Jackson, A.L., Bert, T.M., 2003. Disparate patterns of population genetic structure and population history in two sympatric penaeid shrimp species (Farfantepenaeus aztecus and Litopenaeus setiferus) in the Eastern United States. Mol. Ecol. 12, 2895-2905. http://dx.doi.org/10.1046/j.1365-294X.2003.01955.x.

McMillen-Jackson, A.L., Bert, T.M., 2004. Genetic diversity in the mtDNA control region and population structure in the pink shrimp Farfantepenaeus duorarum. J. Crustacean Biol. 24 (1), 101-109. http://dx.doi.org/10.1651/C-2372.

Melville-Smith, R., Lestang, S., 2006. Spatial and temporal variation in the size of maturity of the western rock lobster Panulirus cygnus George. Mar. Biol. 150, 183-195. http://dx.doi.org/10.1007/s00227-006-0349-6.

Moritz, C., Dowling, T.E., Brown, W.M., 1987. Evolution of animal mitochondrial DNA: relevance for population biology and systematics. Annu. Rev. Ecol. Syst. 18 (1), 269-292. http://dx.doi.org/10.1109/GCE.2010.5676129.

Nei, M., Maruyama, T., Chakraborty, R., 1975. The bottleneck effect and genetic variability in populations. Evolution 29, 1-10.

Neto, J.D., Dornelles, L.D.C., 1996. Diagnóstico da pesca marítima do Brasil. Coleção Meio Ambiente (Séries - Estudos). IBAMA, Brasília, p. 165.

Olden, J.D., Poff, N.L., Douglas, M.R., Douglas, M.E., Fausch, K.D., 2004. Ecological and evolutionary consequences of biotic homogenization. Tr. Ecol. Evol. 19 (1), 18-24. http://dx.doi.org/10.1016/j.tree.2003.09.010.

Olsen, E.M., Heino, M., Lilly, G.R., Morgan, M.J., Brattey, J., Ernande, B., Dieckmann, U., 2004. Maturation trends indicative of rapid evolution preceded the collapse of northern cod. Nature 428 (6986), 932-935. http://dx.doi.org/ 10.1038/nature02430.

Paiva, M.P., 1997. Recursos Pesqueiros Estuarinos Marinhos Do Brasil. Edições UFC, Fortaleza, p. 278.

Palumbi, S.R., 2003. Population genetics, demographic connectivity, and the design of marine reserves. Ecol. Appl. 13 (Special number 1), 146-158. http://dx.doi. org/10.1890/1051-0761(2003. http://dx.doi.org/10.1890/1051-0761(2003)013\% 5B0146:PGDCAT\%5D2.0.CO;2.

Quan, J., Lü, X., Zhuang, Z., Dai, J., Deng, J., Zhang, Y., 2001. Low genetic variation of Penaeus chinensis as revealed by mitochondrial COI and 16S rRNA gene sequences. Biochem. Genet. 39 (7/8), 279-284. http://dx.doi.org/10.1023/A: 1010234816514

Rossi, N., Mantelatto, F.L., 2013. Molecular analysis of the freshwater prawn Macrobrachium olfersii (Decapoda, Palaemonidae) supports the existence of a single species throughout its distribution. PlosOne 8, e54698. http://dx.doi.org/ 10.1371/journal.pone.0054698.

Rozas, J., Rozas, R., 1999. DnaSP version 3.0: an integrated program for molecular population genetics and molecular evolution analysis. Bioinformatics 15 (2), 174-175. http://dx.doi.org/10.1093/bioinformatics/15.2.174y.

Ryman, N., Utter, F., Laikre, L., 1995. Protection of intraspecific biodiversity of exploited fishes. Rev. Fish Biol. Fish. 5, 417-446. http://dx.doi.org/10.1007/ BF01103814.

Seeb, L.W., Seeb, J.E., Plovina, J.J., 1990. Genetic variation in highly exploited spiny lobster Panulirus marginatus populations from the Hawaiian archipelago. Fish. Bull. (U.S.) 88, 713-718.

Spencer, C.C., Neigel, J.E., Leberg, P.L., 2000. Experimental evaluation of the usefulness of microsatellite DNA for detecting demographic bottlenecks. Mol. Ecol. 9, 1517-1528. http://dx.doi.org/10.1046/j.1365-294x.2000.01031.x.

Tamura, K., Peterson, D., Peterson, N., Stecher, G., Nei, M., Kumar, S., 2011. MEGA5: molecular evolutionary genetics analysis using maximum likelihood, evolutionary distance, and maximum parsimony methods. Mol. Biol. Evol. 28 (10), 2731-2739. http://dx.doi.org/10.1093/molbev/msr121.

Terossi, M., Mantelatto, F.L., 2012. Morphological and genetic variability in Hippolyte obliquimanus Dana, 1852 (Decapoda: Caridea: Hippolytidae) from Brazil and the Caribbean Sea. Crustaceana 85 (6), 685-712. http://dx.doi.org/10.1163/ $156854012 X 643762$

Thompson, J.D., Higging D.G., Gibson, TJ., 1994. CLUSTALW: Improving the sensitivity of progressive multiple sequence alignment through sequence weighting specific gap penalties and weight matrix choice. Nucl. Acids Res. 22, 4673-4680. http://dx.doi.org/10.1093/nar/22.22.4673.

Tsuzuki, M.Y., Cavalli, R.O., Bianchini, A., 2003. Effect of salinity on survival, growth, and oxygen consumption of the pink shrimp Farfantepenaeus paulensis (PérezFarfante 1967). J. Shellfish Res. 22 (2), 555-559. http://www.jstor.org/stable/ 1549230.

Vergamini, F.G., Pileggi, L.G., Mantelatto, F.L., 2011. Genetic variability of the Amazon river prawn Macrobrachium amazonicum (Decapoda, Caridea, Palaemonidae). Contrib. Zool. 80 (1), 67-83. http://www.ctoz.nl/vol80/nr01/a03.

Wieman, A.C., Berendzen, P.B., Hampton, K.R., Jang, J., Hopkins, M.J., Jurgenson, J., McNamara, J.C., Thurman, C.L., 2013. A panmictic fiddler crab from the coast of Brazil? Impact of divergent ocean currents and larval dispersal potential on genetic and morphological variation in Uca maracoani. Mar. Biol. 161, 173-185. http://dx.doi.org/10.1007/s00227-013-2327-0.

Winkelmann, I., Campos, P.F., Strugnell, J., Cherel, Y., Smith, P.J., Kubodera, T., 
Allcock, L., Kampmann, M.L., Schroeder, H., Guerra, A., Norman, M., Finn, J., Ingao, D., Clarke, M., Gilbert, M.T.P., 2013. Mitochondrial genome diversity and population structure of the giant squid Architeuthis: genetics sheds new light on one of the most enigmatic marine species. Proc. R. Soc. B 280, 20130273. http:// dx.doi.org/10.1098/rspb.2013.0273.

Walsh, M.R., Munch, S.B., Chiba, S., Conover, D.O., 2006. Maladaptive changes in multiple traits caused by fishing: impediments to population recovery. Ecol.
Lett. 9 (2), 142-148. http://dx.doi.org/10.1111/j.1461-0248.2005.00858.x.

Wright, S., 1931. Evolution in Mendelian populations. Genetics 16, 97-159. http:// www.ncbi.nlm.nih.gov/pmc/articles/PMC1201091/.

Zenger, H.H., Agnes, J.L., 1977. Distribuição do camarão-rosa (Penaeus brasiliensis e Penaeus paulensis) ao longo da costa sudeste e sul do Brasil, 21. Programa de Pesquisa e Desenvolvimento Pesqueiro/Série Documentos Técnicos, Brasília. I II $+1-135$. 